\title{
Lutowanie twarde stopów na osnowie aluminidków
}

\section{Brazing of alloys based on aluminides}

\section{Streszczenie}

W artykule omówiono właściwości i zastosowanie stopów na osnowie faz międzymetalicznych tytanu, niklu i żelaza z aluminium oraz metody łączenia stopów na osnowie tych faz. Przedstawiono wyniki badań technologicznych nad lutowaniem twardym stopów na osnowie faz $\mathrm{TiAl}, \mathrm{Ni}_{3} \mathrm{Al}$, i $\mathrm{Fe}_{3} \mathrm{Al}$, prowadzonych w Instytucie Spawalnictwa w Gliwicach, a także właściwości mechaniczne i badania strukturalne połączeń lutowanych.

\section{Abstract}

Properties and application of alloys based on intermetallic phase titanium, nickel and iron with aluminum. The methods of joining alloys based on this phases. The results of technological researches on brazing of $\mathrm{TiAl}, \mathrm{Ni}_{3} \mathrm{Al}$, and $\mathrm{Fe}_{3} \mathrm{Al}$ based alloys, conducted in Institute of Welding in Gliwice. Mechanical and structural properties of brazed joints.

\section{Wstęp}

W ciągu ostatnich lat coraz większym zainteresowaniem, jako nowoczesne materiały konstrukcyjne o specjalnych właściwościach, cieszą się stopy na osnowie uporządkowanych faz międzymetalicznych, zawierających aluminium, tzw. aluminidki. Stopy te tworzą nową generację materiałów, tzw. intermetali, intermetalików, łączących cechy metali i ceramiki inżynierskiej. Dotychczasowe badania właściwości eksploatacyjnych takich stopów, modyfikowania ich odpowiednimi pierwiastkami chemicznymi celem podwyższenia tych właściwości, a także postęp w zakresie metod ich wytwarzania pozwoliły uznać za najbardziej perspektywiczne stopy na osnowie faz międzymetalicznych z układów Ti-Al, Ni-Al oraz Fe-Al. Stosunkowo duża zawartość metalu lekkiego - aluminium (gęstość $2,7 \cdot 10^{3} \mathrm{~kg} / \mathrm{m}^{3}$ ) sprawia, że stopy na osnowie faz międzymetalicznych z tym pierwiastkiem wykazują również stosunkowo małą gęstość. Tworząca się na ich powierzchni pasywacyjna, trwała chemicznie warstewka tlenku aluminium $\mathrm{Al}_{2} \mathrm{O}_{3}$ zapewnia $\mathrm{z}$ kolei ich doskonałą odporność na korozję, w tym również korozję gazową

Dr inż. Andrzej Winiowski, prof. IS, dr inż. Maciej Różański - Instytut Spawalnictwa, Gliwice. (utlenianie, nawęglanie), nawet w temperaturze przekraczającej $1000^{\circ} \mathrm{C}$. Oprócz wysokiej odporności korozyjnej i odporności na pełzanie oraz rekrystalizację, co wynika z uporządkowania struktury (mały współczynnik samodyfuzji), dodatkowymi, korzystnymi technicznie właściwościami stopów na osnowie faz międzymetalicznych z aluminium są: wysoka przewodność cieplna, żarowytrzymałość, odporność na zmęczenie cieplne, a także, jak już wcześniej wspomniano, mała gęstość. Niestety wadą tych stopów jest niewielka plastyczność i ciągliwość oraz stosunkowo duża twardość. Można te cechy nieco ograniczyć, wprowadzając do nich dodatek odpowiednich pierwiastków chemicznych. Stopy o modyfikowanym tak składzie chemicznym są już obecnie produkowane i w zastosowaniach praktycznych zastępują one „klasyczne” stopy niklu (nadstopy). Podstawowe ich zastosowanie to: wirniki turbosprężarek, zawory i gniazda zaworów, denka łłoków oraz elementy układów wydechowych w silnikach samochodowych, podzespoły silników lotniczych i rakietowych, łopatki turbin gazowych w energetyce i lotnictwie, elementy kotłów i palników, filtry gazowe, wymienniki ciepła, rury, ekrany w przemyśle energetycznym, części maszyn hutniczych (np. rolki podające części do obróbki cieplnochemicznej) i urządzeń w przemyśle petrochemicznym (np. rury, pojemniki, zbiorniki), czy też elementy aparatury chemicznej (np. wymienniki ciepła) odporne 
na korozję gazową, działanie siarki itp. [1, 2]. Stanowią one również osnowę materiałów kompozytowych o podobnym zastosowaniu [1, 3].

Te stosunkowo nowe stopy na osnowie aluminidków są jednak bardzo trudne do łączenia metodami spawalniczymi $[4,13,27]$. Decydują o tym: znaczna zawartość w nich aluminium i skłonność do intensywnego tworzenia na powierzchni bardzo trwałego tlenku tego metalu $\left(\mathrm{Al}_{2} \mathrm{O}_{3}\right)$, mała ciągliwość zarówno w wysokiej, jak i niskiej temperaturze, skłonność do tworzenia pęknięć spawalniczych: krystalizacyjnych, likwacyjnych i ich kombinacji oraz pęknięć powstających w podwyższonej temperaturze. Łączenie ich może odbywać się za pomocą spawania skoncentrowaną wiązką energii (spawanie laserowe, elektronowe), zgrzewania tarciowego, dyfuzyjnego oraz lutowania twardego (dyfuzyjnego). Zaletą stosowania lutowania twardego, a zwłaszcza lutowania dyfuzyjnego dla tych stopów jest to, że utrudniająca ich spawanie, a także zgrzewanie mała ciągliwość w temperaturach pokojowych nie stanowi w tym przypadku bariery ograniczającej stosowanie procesu łączenia i uzyskiwania połączeń dobrej jakości. Ponadto obecność na powierzchni stopów ciągłej warstewki trwałego tlenku $\mathrm{Al}_{2} \mathrm{O}_{3}$ nie jest podczas lutowania głównym problemem technologicznym, jak w przypadku np. zgrzewania dyfuzyjnego [18].

W kraju prowadzone były dotychczas badania nad spawaniem stopów Ti-Al oraz Fe-Al wiązką elektronów oraz nad łączeniem ich przez zgrzewanie dyfuzyjne

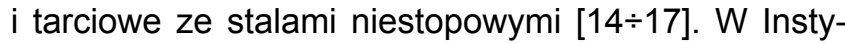
tucie Spawalnictwa w Gliwicach przeprowadzono w ostatnim okresie badania nad lutowaniem twardym (wysokotemperaturowym - dyfuzyjnym) stopów na osnowie faz międzymetalicznych typu TiAl, $\mathrm{Ni}_{3} \mathrm{Al}$ oraz $\mathrm{Fe}_{3} \mathrm{Al}[11,12,22,27]$. Wyniki badań własnych na tle przeglądu osiągnięć zagranicznych w tym zakresie przedstawiono w niniejszej pracy.

\section{Lutowanie stopów na osnowie faz międzymetalicznych Ti-Al}

Od połowy lat 90. ub.w. dużym zainteresowaniem cieszą się stopy tytanu na osnowie uporządkowanych faz międzymetalicznych z układu Ti-Al, w szczególności $\mathrm{Ti}_{3} \mathrm{Al}\left(\alpha_{2}\right)$ i TiAl $(\gamma)$ oraz tzw. stopy dupleks, oparte na obydwu tych fazach. Osnowę tych stopów stanowi najbardziej popularna faza TiAl $(\gamma)$. Charakteryzuje się ona wysoką temperaturą topnienia $\left(1460^{\circ} \mathrm{C}\right)$, stosunkowo małą gęstością $\left(3,8 \cdot 10^{3} \mathrm{~kg} / \mathrm{m}^{3}\right)$, dużą wytrzymałością względną, dobrą odpornością na pełzanie i utlenianie oraz brakiem skłonności do samozapłonu, niekorzystnej dla tytanu. Wykazuje ona również dużą twardość i małą plastyczność. Jej wydłużenie w temperaturze pokojowej wynosi zaledwie $1 \div 3 \%$ i znacząco maleje w obecności nawet niewielkich ilości zanieczyszczeń. Dodatkowo faza TiAl $(\gamma)$ ulega silnemu rozrostowi ziaren podczas przeróbki plastycznej, co praktycznie bardzo utrudnia lub wręcz uniemożliwia tę obróbkę. W celu poprawy tych właściwości do stopów na jej osnowie dodaje się zwykle trzy grupy pierwiastków: podwyższające plastyczność (chrom, mangan, wanad), zwiększające żarowytrzymałość i odporność na korozję gazową oraz utlenienie (niob, tantal, wolfram i molibden) oraz powodujące rozdrobnienie ziarna (bor, węgiel, krzem, tlen oraz metale ziem rzadkich) [1, 2].

Lutowanie stopów tytanu na osnowie faz międzymetalicznych $\operatorname{TiAl}(\gamma)$ i $\operatorname{TiAl}_{3}\left(\alpha_{2}\right)$ w dostępnej literaturze przedstawiono na przykładach lutowania ich z zastosowaniem następujących spoiw: $\mathrm{Ag}, \mathrm{Ag72Cu}$, AgCu26,5Ti3, Al, AlSi12Cu, TiZr35Ni15Cu15, NiCr-

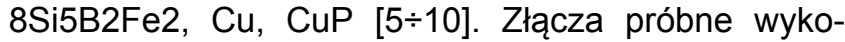
nano zarówno przy stosowaniu krótkich (klasyczne lutowanie twarde), jak i długich (lutowanie dyfuzyjne) czasów lutowania. W większości przypadków dobrą jakość i właściwości mechaniczne złączy uzyskano, stosując stosunkowo szybkie nagrzewanie i krótki czas (do kilku minut) wytrzymania elementów łączonych w temperaturze lutowania.

Na uwagę zasługują prowadzone w tym zakresie badania w Instytucie Spawalnictwa w Gliwicach, których celem było określenie wpływu materiałowo-technologicznych warunków lutowania stopu na osnowie fazy TiAl na strukturę i właściwości mechaniczne połączeń i w efekcie opracowanie najkorzystniejszych warunków technologicznych łączenia tego stopu $[11,12]$. Badaniom poddano stop na osnowie fazy $\operatorname{TiAl}(\gamma)$ o nominalnym składzie chemicznym TiAl48Cr2Nb2, wykonany w warunkach laboratoryjnych w Katedrze Nauki o Materiałach Politechniki Śląskiej w postaci odlewanych wałków. Jako spoiwo (warstwę pośrednią w procesie lutowania dyfuzyjnego) do lutowania tego materiału zastosowano: spoiwo srebrne B-Ag72Cu-780 (Ag 272 wg PN-EN ISO 17672) i miedź. Wszystkie próbki lutowano w piecu próżniowym S 16 firmy TORVAC w próżni w zakresie $10^{-4} \div 10^{-5}$ mbarów. Złącza próbne lutowane spoiwem miedzianym wykonywano w temperaturze lutowania 1000 i $1050^{\circ} \mathrm{C}$, a spoiwem srebrnym - w temperaturze 850,900 i $950^{\circ} \mathrm{C}$. Czas wytrzymania złączy w każdej temperaturze wynosił odpowiednio 1 $\div 30$ min. Uzyskane złącza poddano próbom wytrzymałości na ścinanie oraz badaniom strukturalnym z użyciem mikroskopii świetlnej i elektronowej (skaningowej) wraz ze spektrometrią dyspersji energii (EDS). Największą wytrzymałością (149 MPa) charakteryzowały się złącza lutowane spoiwem srebrnym B-Ag72Cu-780 w temperaturze $900^{\circ} \mathrm{C}$ i czasie $1 \mathrm{~min}$. Wydłużenie czasu do $5 \mathrm{~min}$ spowodowało spadek tej wytrzymałości do $69 \mathrm{MPa}$. Złącza wykonane w temperaturze $950^{\circ} \mathrm{C}$ i przy takich samych czasach (1 i 5 min) wykazały wytrzymałość na ścinanie odpowiednio: 21,7 i $12 \mathrm{MPa}$, a lutowane w temperaturze $850^{\circ} \mathrm{C}$ odpowiednio: 137 i 87,7 MPa. Badania metalograficzne połączeń lutowanych przy dłuższych czasach wytrzymania wykazały wzrost szerokości ich stref dyfuzyjnych, zdominowanych przez kruche złożone fazy Cu-Al-Ti (AICuTi, AlCu2Ti), wraz ze wzrostem temperatury i czasu (rys. 1). 

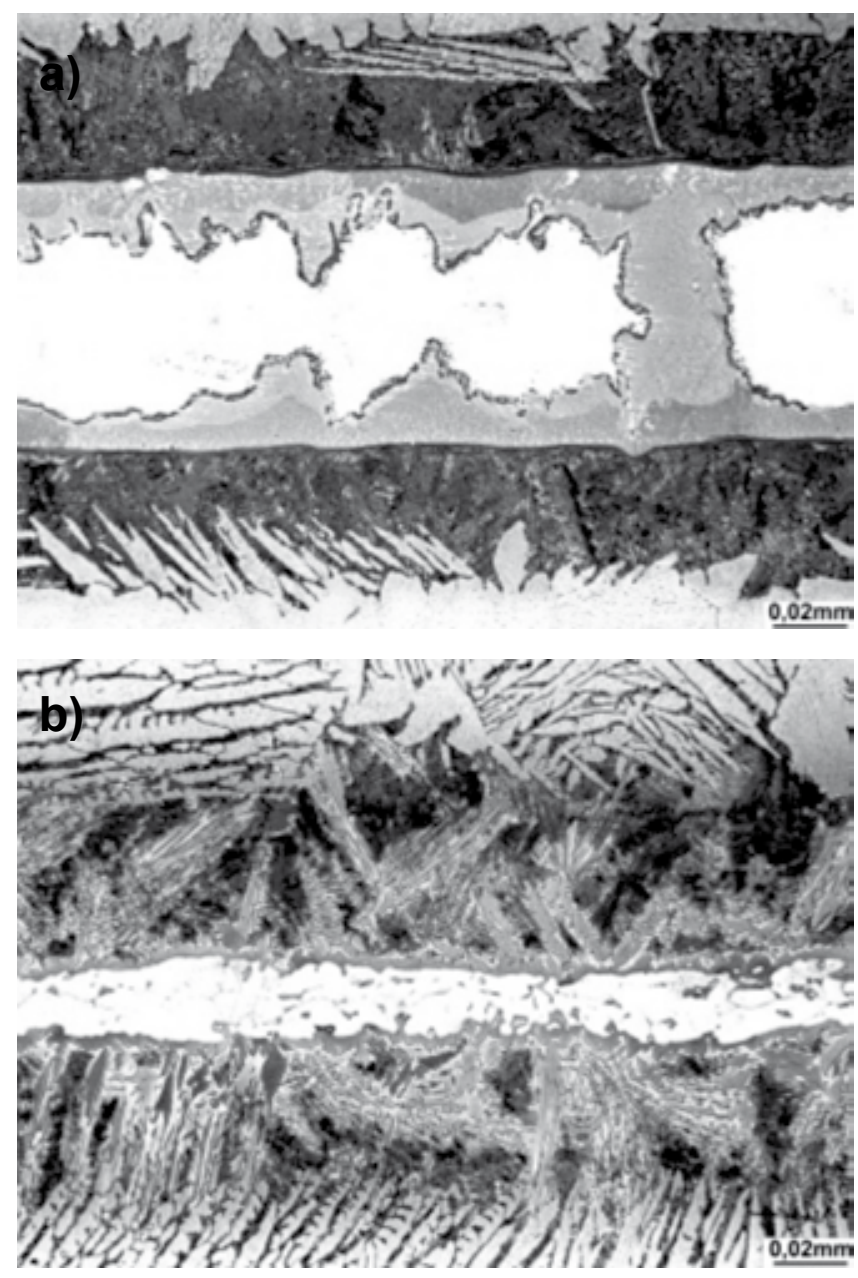

Rys. 1. Struktury połączeń stopu TiAl48Cr2Nb2 lutowanych spoiwem srebrnym B-Ag72Cu-780 w temperaturze $950^{\circ} \mathrm{C}$ i czasie $1 \mathrm{~min}$ (a) oraz 30 min (b). Traw. odcz. Buehlera

Fig. 1. Structures of TiAl48Cr2Nb2 alloy joints brazed with B-Ag72Cu-780 silver filler metal at temperature $950^{\circ} \mathrm{C}$ and holding time $1 \mathrm{~min}(\mathrm{a})$ and $30 \mathrm{~min}$ (b). Etch. Buehler

W przypadku zastosowania miedzi jako spoiwa wytrzymałość na ścinanie złączy wykonanych w temperaturze $1000^{\circ} \mathrm{C}$ i czasie $1 \mathrm{~min}$ nie przekraczała $31 \mathrm{MPa}$, a dla czasu wytrzymania 5 min - $18 \mathrm{MPa}$. Złącza wykonane w temperaturze $1050^{\circ} \mathrm{C}$ wykazały większą wytrzymałość. Wynosiła ona $95 \mathrm{MPa}$ dla czasu 1 min i $78 \mathrm{MPa}$ dla 5 min. Zastosowanie dłuższego niż kilka minut czasu (np. $30 \mathrm{~min}$ ) powodowało całkowite przereagowanie spoiwa $z$ podłożem materiału podstawowego i utworzenie twardej, bardzo kruchej lutowiny o wytrzymałości na ścinanie nieprzekraczającej kilku MPa.

\section{Lutowanie stopów na osnowie faz międzymetalicznych Ni-Al}

Praktyczne, przemysłowe zastosowanie spośród faz międzymetalicznych typu $\mathrm{Ni}-\mathrm{Al}$ znalazły fazy $\mathrm{NiAl}-\beta$ i Ni3Al- $\gamma$ '. Faza Ni-Al występuje w postaci roztworu stałego tworzącego się w temperaturze $1638^{\circ} \mathrm{C}$ i wykazuje małą gęstość $\left(5,9 \cdot 10^{3} \mathrm{~kg} / \mathrm{m}^{3}\right)$, większą od stopów niklu i kobaltu przewodność cieplną (80 W/m.K) oraz odporność na korozję (do $1400^{\circ} \mathrm{C}$ ) i zmęczenie cieplne (żarowytrzymałość do $1200^{\circ} \mathrm{C}$ ). W temperaturze pokojowej charakteryzuje się bardzo małą plastycznością (wydłużenie względne $0 \div 3 \%$ ) zwiększającą się wraz ze wzrostem temperatury (nawet do 6\%). Ze wzrostem temperatury obniża się natomiast wytrzymałość tego materiału na pełzanie. Poprawę tych właściwości mechanicznych można uzyskać przez wprowadzenie do stopów na osnowie fazy Ni-Al dodatku molibdenu, żelaza (nieznaczne podwyższenie plastyczności) oraz chromu, molibdenu, renu, boru i tytanu (podwyższenie odporności na pełzanie) $[1,8 \div 10]$. Faza $\mathrm{Ni}_{3} \mathrm{Al}$ jest roztworem stałym wtórnym, tworzącym się w wyniku przemiany perytektycznej (w temperaturze $1390^{\circ} \mathrm{C}$ ). Gęstość jej wynosi $7,4 \cdot 10^{3} \mathrm{~kg} / \mathrm{m}^{3}$, wydłużenie względne w temperaturze pokojowej od kilku do 50\%. Maksymalna temperatura pracy stopów na jej osnowie nie przekracza $800 \div 1150^{\circ} \mathrm{C}$. Charakterystyczną cechą tej fazy jest podatność na odkształcenia plastyczne przez poślizg wskutek tzw. superdyslokacji, składającej się z pary dyslokacji jednoimiennych całkowitych, której krytyczne naprężenie poślizgu zwiększa się wraz z temperaturą, a tworzenie się domen antyfazowych (między jednoimiennymi dyslokacjami) decyduje o umocnieniu fazy i jej wysokiej wytrzymałości na pełzanie w podwyższonej temperaturze. Stopy na osnowie fazy $\mathrm{Ni}_{3} \mathrm{Al}$, oprócz dobrej odporności na korozję do $800 \div 1150^{\circ} \mathrm{C}$ (w tym odporności na utlenianie i nawęglanie $\mathrm{w}$ atmosferach utleniających i redukujących), stosunkowo wysokiej wytrzymałości doraźnej i na pełzanie oraz granicy plastyczności na ściskanie charakteryzują się wzrastającą wraz z temperaturą bardzo dobrą odpornością na ścieranie w temperaturze wyższej niż $600^{\circ} \mathrm{C}$. Dlatego też są wykorzystywane również do wykonywania powłok na elementach ze stopów niklu, pracujących w trudnych warunkach eksploatacyjnych w podwyższonych temperaturach. Monokryształy $\mathrm{Ni}_{3} \mathrm{Al}$ wykazują też dobrą plastyczność, lecz stopy polikrystaliczne są już znacznie mniej plastyczne. Może w nich występować w atmosferze powietrza, w temperaturze pokojowej, skłonność do transkrystalicznego przełomu w wyniku oddziaływania wodoru atomowego, tzw. kruchość wodorowa. Do stopów na osnowie fazy $\mathrm{Ni}_{3} \mathrm{Al}$ wprowadza się często jako dodatki stopowe: chrom, cyrkon, hafn, molibden i bor [1].

Dostępne w literaturze opracowania z zakresu luto-

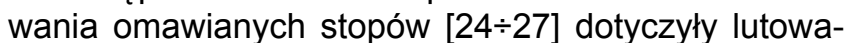
nia dyfuzyjnego (w ograniczonym zakresie parametrów temperaturowych i czasowych) stopów na osnowie fazy $\mathrm{Ni}-\mathrm{Al}$ (poli- i monokrystalicznego) z użyciem przekładki ze spoiwa niklowego BNi-3 wg AWS (NiSi4,5B3,2 temperatura topnienia $984 \div 1054^{\circ} \mathrm{C}$ ), czystej miedzi i czystego aluminium, a w przypadku stopu na osnowie fazy $\mathrm{Ni}_{3} \mathrm{Al}$ lutowania jedynie $\mathrm{z}$ zastosowaniem spoiwa aluminiowego. Badania z użyciem spoiwa niklowego i miedzianego poszerzono o próby lutowania stopu na osnowie fazy Ni-Al z niklem i nadstopem MM-247. Procesy lutowania prowadzono w próżni, stosując 
nagrzewanie oporowe - bezpośrednie, indukcyjne i oporowe piecowe (zróżnicowane szybkości nagrzewania próbek do temperatury lutowania). We wszystkich opracowaniach przedstawiono wyniki badań strukturalnych wyjaśniających mechanizmy tworzenia połączeń lutowanych. Autorzy nie przedstawili jednak wyników badań właściwości (zwłaszcza właściwości

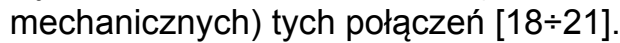

Badania nad lutowaniem stopu na osnowie fazy $\mathrm{Ni}_{3} \mathrm{Al}$ - $\gamma^{\prime}$ (Ni87Al13 - wykonanego w Katedrze Inżynierii Stopów i Kompozytów Odlewanych na Wydziale Odlewnictwa w Akademii Górniczo-Hutniczej w Krakowie) prowadzono również w Instytucie Spawalnictwa w Gliwicach [22]. Celem tych badań było, podobnie jak w przypadku stopu na osnowie fazy Ti-Al, określenie wpływu materiałowo-technologicznych warunków procesu lutowania na właściwości mechaniczne i strukturalne połączeń lutowanych, a w efekcie opracowanie najkorzystniejszych warunków technologicznych łączenia tego stopu. Jako spoiwo w przeprowadzonych badaniach zastosowano czyste aluminium oraz czystą miedź, a także lut srebrny B-Ag72Cu-780. Wszystkie próbkilutowanow piecu próżniowym S 16 firmy TORVAC w próżni w zakresie $10^{-3} \div 10^{-5}$ mbarów. Procesy lutowania złączy próbnych prowadzono zarówno przy stosowaniu krótkich (klasyczne lutowanie), jak i długich (lutowanie dyfuzyjne) czasów lutowania. Parametry lutowania stopu wynosiły odpowiednio: w przypadku spoiwa aluminiowego - temperatura lutowania $1000 \div 1150^{\circ} \mathrm{C}$, czas $10 \div 120$ min, w przypadku spoiwa miedzianego - temperatura lutowania $1150^{\circ} \mathrm{C}$, czas $60 \div 180 \mathrm{~min}$., a w przypadku spoiwa srebrnego B-Ag72Cu-780 - temperatura lutowania $1000 \div 1150^{\circ} \mathrm{C}$, czas $30 \div 180 \mathrm{~min}$. Dla uzyskanych w tych warunkach technologicznych złączy próbnych przeprowadzono próby wytrzymałości na ścinanie oraz badania metalograficzne i strukturalne z zastosowaniem mikroskopii świetlnej i elektronowej (skaningowej) wraz z analizą faz przy użyciu spektrometru dyspersji energii (EDS). Statystyczna próba na ścinanie wykazała najkorzystniejsze wyniki dla złączy wykonanych spoiwem srebrnym B-Ag72Cu-780 (165 MPa), przy stosowaniu najniższych parametrów temperaturowo-czasowych lutowania $\left(1000^{\circ} \mathrm{C} / 30 \mathrm{~min}\right)$. Ze wzrostem temperatury i czasu wytrzymałość ta ulegała zmniejszeniu, bardzo znacznemu już w temperaturze $1150^{\circ} \mathrm{C}(3 \div 5 \mathrm{MPa})$. Wyjaśniły to w znacznym stopniu badania strukturalne, wskazujące na tworzenie się w złączu dużej ilości kruchych roztworów na osnowie fazy $\mathrm{Ni}_{3} \mathrm{Al}$ oraz niezgodności typu pustki (rys. 2).

Dla połączeń wykonanych spoiwem miedzianym wytrzymałość określono jedynie w przypadku zastosowania czasu 180 min. Wyniosła ona $110 \mathrm{MPa}$, a strukturę złącza stanowiły roztwory stałe typu Cu-Ni. Złącza próbne wykonane tym spoiwem przy krótszych czasach (60 i 120 min) wykazywały znaczne braki zwilżenia powierzchni łączonej i ulegały rozdzieleniu bez przyłożenia większych sił.

Stosunkowo najmniejszą wytrzymałość na ścinanie wykazały połączenia wykonane spoiwem aluminio-
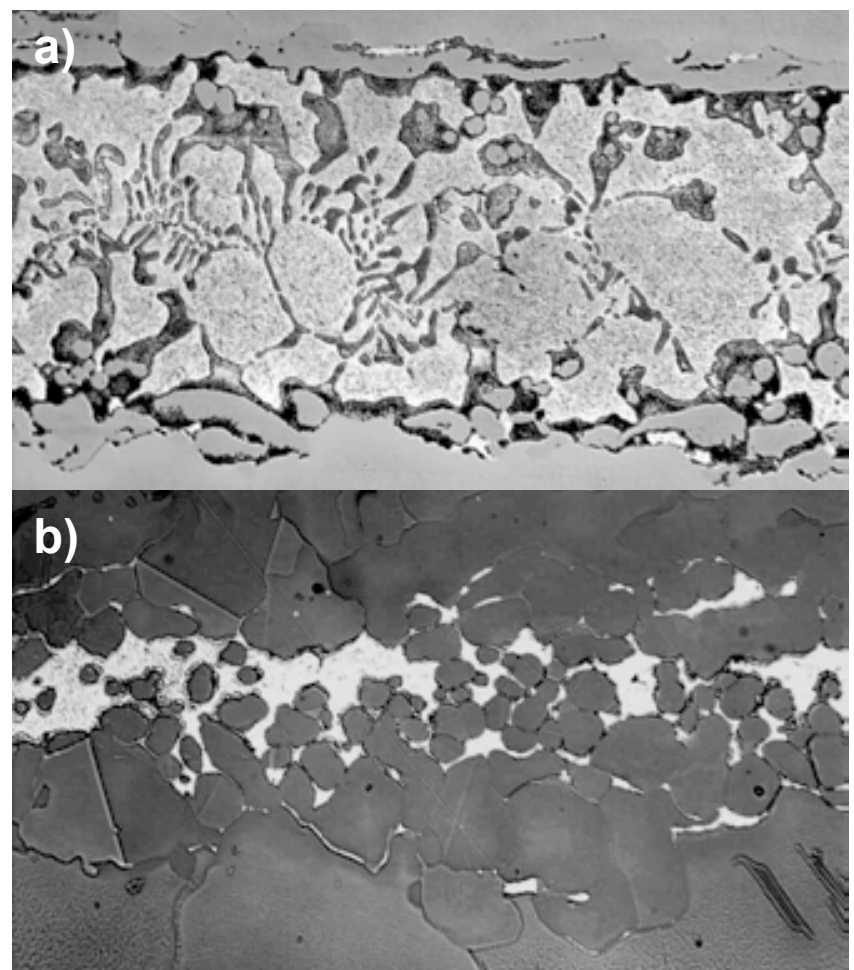

Rys. 2. Struktury połączeń stopu Ni87Al13 lutowanych spoiwem srebrnym B-Ag72Cu-780 w temperaturze $1000^{\circ} \mathrm{C}$ i czasie 30 min (a) oraz temperaturze $1000^{\circ} \mathrm{C}$ i czasie $180 \mathrm{~min}$ (b). Traw. $10 \mathrm{ml} \mathrm{HNO}_{3}+$ $20 \mathrm{ml} \mathrm{HCl}+30 \mathrm{ml}$ gliceryny.

Fig. 2. Structures of Ni87Al13 alloy joints brazed with B-Ag72Cu-780 silver filler metal at temperature $1000^{\circ} \mathrm{C}$ and holding time $30 \mathrm{~min}$ (a) as well as at temperature $1000^{\circ} \mathrm{C}$ and holding time $180 \mathrm{~min}$ (b). Etch. $10 \mathrm{ml} \mathrm{HNO}_{3}+20 \mathrm{ml} \mathrm{HCl}+30 \mathrm{ml}$ glycerol

wym. Największą wartość tej wytrzymałości (28 MPa) uzyskano dla połączeń lutowanych w najniższej temperaturze $\left(1000^{\circ} \mathrm{C}\right)$ i najkrótszym czasie (10 min). W dalszych badaniach stwierdzono, że ze wzrostem temperatury i czasu lutowania ta wytrzymałość maleje.

\section{Lutowanie stopów na osnowie faz międzymetalicznych Fe-Al}

Żelazo z aluminium tworzy układ równowagi fazowej z licznymi fazami międzymetalicznymi. Jednak tylko fazy $\mathrm{Fe}_{3} \mathrm{Al}$ i FeAl stanowią użytkową osnowę stopów konstrukcyjnych. Stopy takie oprócz odporności na korozję gazową (na utlenianie, nawęglanie i działanie siarki), na korozję w wodzie morskiej i stopionych solach oraz odporności na ścieranie, erozję i kawitację, charakteryzują się wysoką rezystywnością elektryczną, przewyższająca nawet o 50\% rezystancję elektryczną stopów, powszechnie stosowanych na elementy grzejne. Wykazują one wprawdzie nieco większą gęstość niż np. fazy z układu Ti-Al (FeAl - 5,3.10 $\mathrm{kg} / \mathrm{m}^{3}$, $\mathrm{Fe}_{3} \mathrm{Al}-6,7 \cdot 10^{3} \mathrm{~kg} / \mathrm{m}^{3}$ ), lecz charakteryzują się stosunkowo niską ceną w porównaniu $z$ innymi stopami na osnowie faz międzymetalicznych. Ich wadą jest mała plastyczność i skłonność do kruchego pękania w temperaturze pokojowej, w atmosferze powietrza oraz pary 
wodnej. Wykazują one anormalność wytrzymałości na rozciaganie w funkcji temperatury (wzrasta w zakresie $300 \div 600^{\circ} \mathrm{C}$, a następnie znacznie obniża się). Podwyższenia ich plastyczności i odporności na kruche pękanie dokonuje się przez odpowiedni dobór składu chemicznego, modyfikację mikrostruktury, zmniejszenie stopnia uporządkowania atomów oraz stosowanie powłok ochronnych [1].

Znalezione w literaturze specjalistycznej opracowania z zakresu lutowania dyfuzyjnego (z nagrzewaniem promiennikami podczerwieni w próżni) stopów na osnowie faz z układu Fe-Al dotyczyły tylko stopów na osnowie fazy $\mathrm{Fe}_{3} \mathrm{Al}$ i obejmowały stosowanie spoiw-przekładek ze spoiwa niklowego BNi-2 wg AWS 5.8 (NiCr8Si5B3 o temperaturze topnienia $971 \div 999^{\circ} \mathrm{C}$ ), spoiwa złotego AuCu20 (roztwór stały z min. punktem topnienia $910^{\circ} \mathrm{C}$ ), czystego aluminium i czystej miedzi

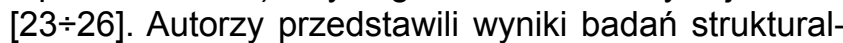
nych złączy, wyjaśniające mechanizm ich powstawania, a także w niektórych przypadkach podali właściwości wytrzymałościowe połączeń. W przypadku połączeń wykonanych spoiwem niklowym BNi-2 najkorzystniejszą wytrzymałość na ścinanie $291 \mathrm{MPa}$ uzyskano dla temperatury lutowania $1100^{\circ} \mathrm{C}$ i czasu $300 \mathrm{~s}$ [26].

Badania nad lutowaniem stopu na osnowie fazy $\mathrm{Fe}_{3} \mathrm{Al}$ (Fe86Al14 - wykonany w Katedrze Inżynierii Stopów i Kompozytów Odlewanych na Wydziale Odlewnictwa w Akademii Górniczo-Hutniczej w Krakowie) prowadzono również w Instytucie Spawalnictwa w Gliwicach [27]. Jako spoiwa zastosowano: luty miedziano-niklowe B-Cu95Ni, a także $1085 / 1120$ oraz BCu90Ni - 1100/1140 oraz stosowany z powodzeniem we wcześniejszych pracach do łączenia stopów Ti-Al oraz Ni-Al lut srebrny typu Ag-Cu-B-Ag72Cu-780. W badaniach dążono do określenia wpływu materiałowych i technologicznych warunków procesu lutowania na właściwości mechaniczne i strukturalne połączeń i ustalenia najkorzystniejszych warunków technologicznych lutowania stopu Fe86Al14. Złącza próbne wykonano w piecu próżniowym S 16 firmy TORVAC w próżni w zakresie $10^{-4} \div 10^{-5} \mathrm{mbar}$, stosując następujące parametry procesu: w przypadku spoiw Cu-Ni temperatura lutowania $1170 \div 1200^{\circ} \mathrm{C}$, czas $30 \div 180 \mathrm{~min}$, w przypadku spoiwa srebrnego B-Ag72Cu-780 temperatura lutowania $1000 \div 1150^{\circ} \mathrm{C}$, czas $30 \div 300 \mathrm{~min}$. Dla uzyskanych w tych warunkach technologicznych złączy próbnych przeprowadzono próby wytrzymałości na ścinanie oraz badania strukturalne z wykorzystaniem mikroskopii świetlnej i elektronowej (skaningowej) wraz z analizą przy użyciu spektrometru dyspersji energii (EDS). Największą wytrzymałością na ścinanie charakteryzowały się połączenia wykonane lutami miedziano-niklowymi B-Cu90Ni-1100/1140 (233 MPa) i B-Cu95Ni-1120/1085 (202 MPa) w temperaturze lutowania $1200^{\circ} \mathrm{C}$ i czasie $60 \mathrm{~min}$. Mniejszą wytrzymałość połączeń (130 MPa) uzyskano przy lutowaniu lutem srebrnym B-Ag72Cu-780 dla parametrów lutowania: $1000^{\circ} \mathrm{C} / 300 \mathrm{~min}$ i $1150^{\circ} \mathrm{C} / 120 \mathrm{~min}$. Badania strukturalne złączy wykazały, że w złączach wykonanych spoiwami miedziano-niklowymi powstają dyspersyjne wydzielenia fazy o składzie chemicznym odpowiadającym fazie $\mathrm{Fe}_{3} \mathrm{Al}$, które wraz ze wzrostem temperatury i wydłużeniem czasu procesu ulegają koagulacji, a składniki spoiwa reagują z materiałem łączonym, tworząc kruche strefy dyfuzyjne (rys. 3).

W złączach tych stwierdzono występowanie nieznacznych ilości niezgodności w postaci pustek, charakterystycznych dla połączeń lutowanych dyfuzyjnie (tzw. efekt Kirkendalla).

Struktury połączeń wykonanych przy użyciu lutu B-Ag72Cu-780 wykazywały roztworzenie lutu eutektycznego i wydzielenie roztworów stałych w postaci dwóch niekoherentnych faz o dużej zawartości srebra i miedzi. Pomiędzy tymi fazami występowały niekiedy pęknięcia w lutowinach, które jednak zanikały wraz z wydłużeniem czasu lutowania.
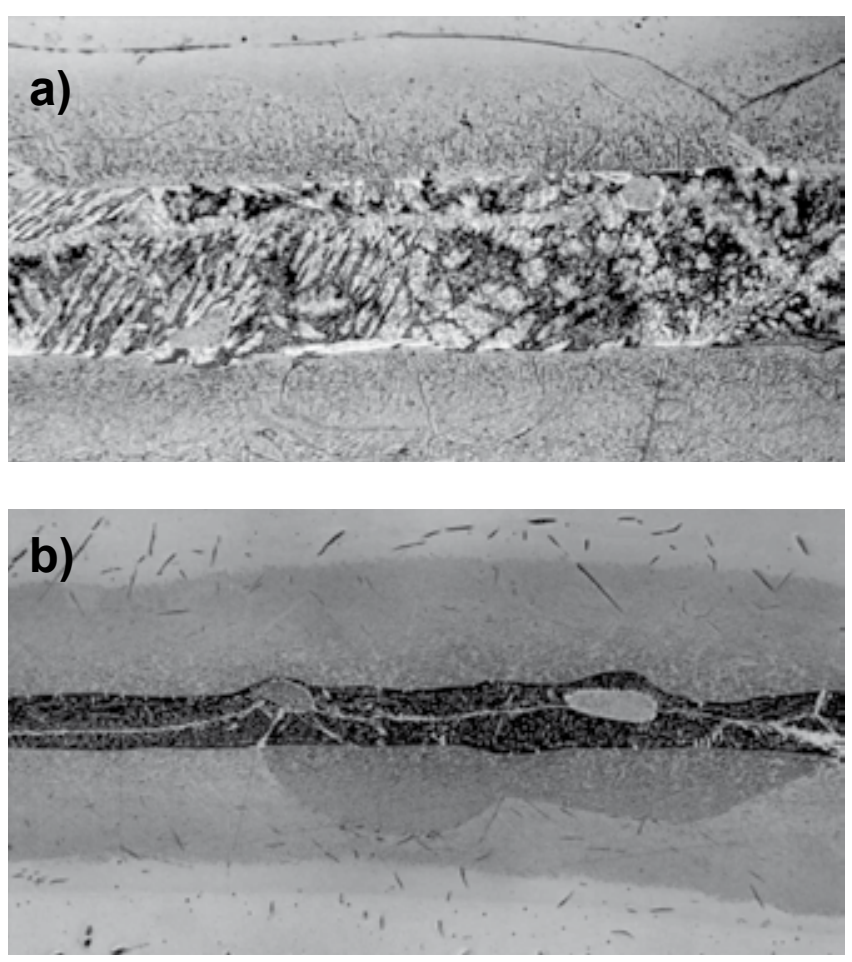

Rys. 3. Struktury połączeń stopu Fe86Al14 lutowanych spoiwem miedziano-niklowym B-Cu90Ni-1100/1140 w temperaturze $1200^{\circ} \mathrm{C}$ i czasie 60 min (a) oraz $180 \mathrm{~min}$ (b). Traw. $10 \mathrm{ml} \mathrm{HNO}_{3}+20 \mathrm{ml} \mathrm{HCl}$ $+30 \mathrm{ml}$ gliceryny

Fig. 3. Structures of Fe86Al14 alloy joints brazed with B-Cu$90 \mathrm{Ni}-1100 / 1140$ copper - nickel filler metal at temperature $1200^{\circ} \mathrm{C}$ and holding time $60 \mathrm{~min}$ (a) and $180 \mathrm{~min}$ (b). Etch. $10 \mathrm{ml} \mathrm{HNO}+20 \mathrm{ml}$ $\mathrm{HCl}+30 \mathrm{ml}$ glycerol 


\section{Podsumowanie}

Wobec trudności metalurgicznych i technologicznych podczas spawania nowoczesnych stopów na osnowie faz międzymetalicznych z układów Ti-Al, $\mathrm{Ni}-\mathrm{Al}$ i Fe-Al, zastępujących w wielu zastosowaniach „klasyczne” stopy tytanu i niklu, twarde lutowanie dyfuzyjne jest alternatywną, korzystną technicznie metodą ich łączenia. Przeprowadzone dotychczas badania w tym zakresie $z$ zastosowaniem spoiw niklowych, miedzianych, srebrnych itp. wykazały, że największą wytrzymałość uzyskuje się dla krótszych czasów lutowania. Złącza takie charakteryzują się jednak stosunkowo małą żaroodpornością. Z kolei złącza uzyskane dla długich czasów wytrzymania, poddane przemianom dyfuzyjnym i charakteryzujące się w ich efekcie strukturą złożoną z żaroodpornych, wyżej topliwych, lecz kruchych faz, wykazują dużą żaroodporność i stosunkowo małą wytrzymałość. W niektórych publikacjach, zwłaszcza dotyczących lutowania stopów na osnowie faz Ni-Al, aspekt

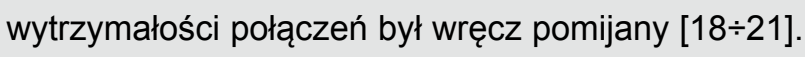
Wśród prowadzonych dotychczas badań materiałowo-technologicznych w tym zakresie na uwage zasługują wyniki badań wykonanych w Instytucie Spawalnictwa w Gliwicach. Dotyczyły one lutowania twardego (wysokotemperaturowego) dyfuzyjnego stopów na osnowie faz międzymetalicznych Ti-Al, $\mathrm{Ni}_{3} \mathrm{Al}$ oraz $\mathrm{Fe}_{3} \mathrm{Al}$ spoiwami B-Ag72Cu-780, Cu, Al, B-Cu95Ni - 1085/1120 oraz B-Cu90Ni - 1100/1140. Badania te potwierdziły $w$ dużej mierze przedstawione powyżej spostrzeżenia, uzupełniając przyczyny obniżenia wytrzymałości połączeń dyfuzyjnych, uzyskanych przy stosowaniu długich czasów prowadzenia procesu, o pustki Kirkendalla. Pozwala to wnioskować, że dobór temperaturowo-czasowych parametrów lutowania dla poszczególnych przypadków zastosowań przedmiotowych stopów na osnowie aluminidków powinien wynikać z wymagań dotyczących żaroodporności i żarowytrzymałości połączeń.

\section{Literatura}

[1] Praca zbiorowa pod red. Z. Bojara i W. Przetakiewicza: Materiały metalowe z udziałem faz międzymetalicznych. BEL Studio, Warszawa 2006.

[2] Szkliniarz W.: Stopy na osnowie faz międzymetalicznych z układu Ti-Al. Wydawnictwo Politechniki Śląskiej, Gliwice 2007.

[3] Ward-Close C.M., Minor R., Doorbar P.J.: Intermetallic - matrix composites - a review Intermetalics 4, 1996, s. 217-229.

[4] Baeslack W.A., Mascorella T.J., Kelly T.J.: Weldability of titanium aluminide. Welding Journal nr 10, 1989, s. 483s-498s.

[5] Shine R.K., Wu S.K., Chen S.Y.: Infrared brazing of TiAl intermetallic using B-Ag8 braze alloy. Acta Materialia nr 51/2003, s. 1991-2004.

[6] He P., Feng J.C., Zhou H.: Microstructure and strength of brazed joints of $\mathrm{Ti}_{3} \mathrm{Al}$ - base alloy with $\mathrm{NiCrSiB}$. Materials Characterization nr 4-5/2004, s. 309-318.

[7] He P., Feng J.C., Zhou H.: Microstructure and strength of brazed joints of Ti3Al - base alloy with TiZrNiCu. Materials Science and Engineering A392, 1-2/2005, s. 81-86.

[8] He P., Feng J., Zhou H.: Microstructure and strength of brazed joints of $\mathrm{Ti}_{3} \mathrm{Al}$ - base alloy with Cu-P filler metal. J. Mater. Sci. Technol., vol. 21, nr 4, 2005, s. 493-498.

[9] Shiue R.K., Wu S.K., Chen S.Y.: Infrared brazing of TiA using Al-based alloys. Intermetallics 11, 2003, s. 661-671.

[10] Gale W.F.: Applying TLP bonding to the joining of structural intermetallic compounds. Journal of Metals $\mathrm{nr} 2 / 1999$, s. 49-52.

[11] Winiowski A., Różański M.: Diffusive brazing of titanium and its alloys with alumininum in the TiAl phase matrix. Welding International. vol.25, nr 5, 2008, s. 104-110.

[12] Mirski Z., Różański M.: Diffusion brazing of titanium aluminide alloy based on TiAl. Archive of Civil and Mech. Eng. Vol. 13, no. 3/2013.

[13] David S.A., Jemian W.A., Liu C.T., Horton J.A.: Welding and weldability of nickel - iron aluminides. Welding Journal $\mathrm{nr} 1$, vol. 64 1985, s. 22s-28s.

[14] Adamiec J., Sozańska M., Lasertowa M., Hyspecka L.: Makro i mikrostruktura połączeń spajanych stopu $\mathrm{Ni}_{3} \mathrm{Al}$ z niklem wykonanych wiązką elektronów. Inżynieria Mater. Nr 4, 2004.
[15] Adamiec J., Grabowski A., Lisowski A.: Joining of an Ni-Al alloy by means of laser beam welding. Proceedings of SPIE - The International Society For Optical Engineering, 2002.

[16] Włosiński W., Jakubowski J., Krajewski A., Woźniczka M.: Zgrzewanie dyfuzyjne stopów na bazie $\mathrm{NiAl}$ i $\mathrm{Ni}_{3} \mathrm{Al}$ ze stalą St3S. Przegląd Spawalnictwa nr 2-3, 2005.

[17] Włosiński W., Chmielewski T., Kucharczyk M.: Spajanie tarciowe stopów NiAl i FeAl ze stalą węglową St3S. Przegląd Spawalnictwa nr 1, 2004.

[18] Gale W.F.: Diffusion brazing of advanced materials. Mat. Międzynarodowego Kolokwium „Brazing high temperature brazing and diffusion welding”, Achen, 1995, s. 7-11.

[19] Gale W.F., Guan Y.: Transient liquid phase bonding in the $\mathrm{NiAl} / \mathrm{Cu} / \mathrm{Ni}$ system - a microstructural investigation. Metallurgical and Materials Trans. A, vol. 27A, nr 11, 1996, s. 36213629.

[20] Yang T.Y., Wu S.K., Shiue R.K.: Interfacial reaction of infrared brazed $\mathrm{NiAl} / \mathrm{Al} / \mathrm{NiAl}$ and $\mathrm{Ni}_{3} \mathrm{Al} / \mathrm{Al} \mathrm{Ni}{ }_{3} \mathrm{Al}$ joints. Intermetallics 9, 2001, s. 341-347.

[21] Orel S.V., Parous L.C., Gale W.L.: Diffusion brazing of nickel aluminides. Welding Journal, nr 9, 1995, s. 319s - 324s.

[22] Winiowski A., Różański M.: Brazing of alloys based on intermetallic phase $\mathrm{Ni}_{3} \mathrm{Al}$. Metallic Materials, vol.51, $\mathrm{nr} 2,2013$.

[23] Li Z., Shiue R.K., Wu S.K.: Infrared brazing $\mathrm{Fe}_{3} \mathrm{Al}$ intermetallics using the $\mathrm{Cu}$ filler metal. Intermetallics 18, 2010, s. 422-428.

[24] Shiue R.K., Wu S.K., Lee Y.L.: Transient microstructure evolution of infrared brazed $\mathrm{Fe}_{3} \mathrm{Al}$ intermetallics using aluminium foil. Intermetallics 13, 2005, s. 818-826.

[25] Shiue R.K., Wu S-K., Li I-H.: Infrared brazing of $\mathrm{Fe}_{3} \mathrm{Al}$ intermetallic compound using gold-based braze alloy. Gold Bull, 2011,44-49-56; DOI 10.1007/s13404-011-0007-8. Springer. s. $49-56$.

[26] Lee Y.L., Shiue R.K., Wu S.K.: The microstructural evoluation of infrared brazed $\mathrm{Fe}_{3} \mathrm{Al}$ by $\mathrm{BNi}-2$ braze alloy. Intermetallics 11, 2003, s.187-195.

[27] Różański M., Winiowski A.: Lutowanie twarde stopów na osnowie faz międzymetalicznych typu Fe-Al. Sprawozdanie z pracy badawczej IS nr Cc-53/1 (ST-307/1), 2012. 